\title{
Factors affecting drivers' willingness to pay for biofuels: the case of Italy
}

\author{
Pietro Lanzini ${ }^{\mathrm{a},}{ }^{*}$, Francesco Testa ${ }^{\mathrm{b}}$, Fabio Iraldo ${ }^{\mathrm{b}, \mathrm{c}}$ \\ a Department of Management, Università Cà Foscari, Cannaregio 873, 30121 Venezia, Italy

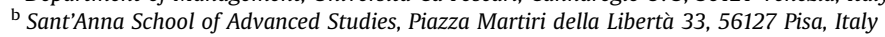

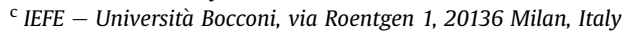

Keywords:

Biofuels

Certification

Willingness to pay

\begin{abstract}
A B S T R A C T
Biofuels represent a promising alternative to substitute fossil fuels and, given the relevance of environmental impacts of the transport sector, policy initiatives worldwide aim at supporting the shift towards such cleaner energy source. Acknowledging the crucial role that biofuels will play in years to come in the energetic paradigm, the study aims at investigating key-determinants of drivers' willingness to pay for biofuels, focusing on a sample of 260 individuals from Northern Italy $(n=260)$. In line with recent research on consumer behavior, socio-demographics are not good predictors of drivers' willingness to pay. Surprisingly, on the other hand, knowledge of the topic is negatively correlated to willingness to pay, so that the more people know about biofuels, the less they are willing to pay a premium price. Moreover, certification is not an effective tool to convince drivers of the eco-friendliness of biofuels, hence spurring willingness to pay. Possible explanations of the research findings as well as policy implications are discussed in detail, along with suggestions for future research on the topic.
\end{abstract}

(c) 2015 Elsevier Ltd. All rights reserved.

\section{Introduction}

Since the green revolution of the 1970s, the increasing environmental awareness of large sectors of the market spurred companies to focus on the eco-friendliness of their products and services.

The willingness of consumers to pay a premium for a green offer was among the driving factors of such process. Marketing campaigns advertised as green also products for which the effective benefits to the environment were, at best, limited and superficial. As a consequence of this so-called greenwashing phenomenon, consumers dazed by the hype of environmental claims developed in recent years diffidence in green claims that often reached open mistrust. To cope with this barrier erected by consumers, companies can rely on certification schemes with green labels being released by independent bodies to certify that a given product complies with specific environmental criteria.

The article fills a gap in literature by focusing on the biofuel sector, analyzing specific dimensions that received so far little

\footnotetext{
* Corresponding author.

E-mail address: lanzini@unive.it (P. Lanzini).
}

attention by empirical analyses. We want to investigate the effects of different determinants of consumers' Willingness To Pay (WTP) for a product that a) has significant environmental impacts and b) is almost completely undifferentiated, and to assess whether hypothetical green labels for biofuels "at the pump" might make a difference.

The specific choice of the sector investigated has been driven by the consideration that biofuels represent the perfect ground for testing our hypotheses: they are a sheer example of products where the environmental friendliness is the only dimension (other than price) on which producers can differentiate their offer. Consumers' WTP could be hence genuinely ascribed to the sustainability of the product, with no intertwining effects of other qualitative variables as in the case of most product categories. Our article provides an added value not only by building new empirical evidence on a topic which gained broad relevance in the ongoing debate on future energy scenarios; indeed, to the knowledge of the authors, it represents the first empirical investigation aimed at analyzing if and how certification schemes would be able to affect consumers' WTP for biofuels. Moreover, while existing labeling initiatives focus on the upstream relationships between feedstock producers, industrial processors and distributors, the article aims at shedding light on the so-far unexplored aspect of downstream certification. The 
focus is indeed on end-consumers and their willingness to award a premium price to biofuels labeled as green, this representing a novelty aspect of the paper.

The article is organized as follows. After introducing the biofuel sector and existing evidence on consumers' WTP, we provide an overview on the theoretical framework of consumer behavior in the domain of sustainability, introducing the research hypotheses aimed at investigating the role of variables such as sociodemographics or biofuel knowledge in spurring WTP. The subsequent section is dedicated to an overview on green certification, and the relative research hypothesis on the role of green labels.

The Methods section describes how we gathered data for a cross-sectional study based on a sample of 260 individuals living in Northern Italy $(n=260)$. Also, the statistical model adopted for the analyses is described, and the variables specified, in detail. The Results section presents the evidence emerging from the statistical analysis of the dataset, while in the Discussion and Conclusions section we provide a thorough interpretation of them. Insights on policy implications and hints for future research building on the knowledge developed are also presented.

\section{Biofuels: overview and consumers' WTP}

Do biofuels work? This is the tormenting question that practitioners and scholars are constantly confronted with (Chum et al., 2014; Frank et al., 2013). The increasing relevance of the debate on biofuels and the contradictory evidence emerging from both media and academia spurred indeed great interest and curiosity within the public at large. Clearly, the elusive answer to such a broad question has to be it depends, given the extreme heterogeneity of variables that lead to different products we gather under the umbrella of the term biofuels.

Considered only few years ago as the panacea of all energetic concerns, since 2005/6 biofuels faced a sudden drop in popularity among media and international experts. Drawbacks and shortcomings associated with the production of traditional (i.e. first generation) biofuels can range from the competition for land to the consequent increase in agricultural prices (Zilberman et al., 2013), or even from limited benefits in terms of GHG emissions (Cherubini et al., 2009; Searchinger et al., 2008) to community acceptance problems (Chin et al., 2014) and technical barriers (Browne et al., 2012). As a consequence, a thorough reconsideration of the appeal or even acceptability of a steady development of biofuel production took place (Doornbosch and Steenblik, 2007; Rathmann et al., 2010).

The current debate on the drawbacks of traditional biofuels (ethanol and biodiesel) is consistent with a broad consensus over the necessity to ensure that biofuels and their feedstock are produced, traded and distributed according to specific social and environmental conditions.

So-called advanced, or second generation (2G) biofuels such as cellulosic ethanol, although still in the early stages of commercialization, represent a promising alternative in the attempt of overcoming the drawbacks of traditional biofuels (Graham-Rowe, 2011,Tilman et al., 2009).

Many studies adopting the Life Cycle Analysis (LCA) methodology have been conducted on $2 \mathrm{G}$ biofuels, and findings suggest that these are indeed capable to achieve (far) better environmental performances compared to traditional, food-crop based biofuels; in primis, advantages refer to limited GHG emissions and absence of competition for land (Borrion et al., 2012; Börjesson and Tufvesson, 2011; Fleming et al., 2006; Spatari et al., 2010; Williams et al., 2009; Wiloso et al., 2012). However, there are still uncertainties and open issues regarding the effects of different variables and the subsequent variability in LCA outcomes.
First, productivity and environmental performance of $2 \mathrm{G}$ biofuels depend on both the typology of feedstock (corn stover, switchgrass, jatropha, Solid Municipal Waste - SMW, and son on), and to its geographical location. Since the sustainability of a given plant used as biofuel feedstock could vary significantly according to the specificities of the region where it grows, using standard values in LCAs could be misleading and should be avoided (Hoefnagels et al., 2010).

Second, other methodological issues related to LCA implementation need to be addressed, such as a clear definition of system boundaries, functional units and allocation methods (Singh et al., 2010; Cherubini et al., 2009).

There is also evidence that $2 \mathrm{G}$ biofuels encompass feedstockspecific sustainability drawbacks. Examples can be the depletion of soil nutrients deriving from the removal of crop residues as in the case of corn stover (Liska et al., 2014), or deforestation to produce woody biomass (Dragojlovic and Einsiedel, 2015). With this respect, Fargione et al. (2008) suggest to plant perennials on degraded or abandoned agricultural lands, as to avoid carbon debt and deforestation.

Albeit in recent years the steady increase in the production of biofuels diminished due to the intertwining effects of the economic crisis affecting global energy demand and the discussion on the drawbacks of first-generation biofuels, arguably the years to come will experience an ever increasing production of biofuels (and, specifically, 2G biofuels). Many Countries and Regional Groupings are indeed active in implementing policies envisaging a gradual substitution of fossil fuels in the transport sector with fuels from renewable energy sources (e.g. the Energy Independence and Security Act of 2007 in the US, Directive 2009/28/EC in the EU or PROALCOOL Programme in Brazil). To date, in most Countries (including Italy, where our study was carried out) biofuels are sold blended with fossil fuels at every gas station. However, in some Countries such as the US, Sweden or Brazil, there are already pumps specifically dedicated to biofuels; the path is clearly pointing to a market where drivers will be increasingly able to choose what type of fuel to buy at the filling station. In future years certification schemes could be hence useful even for a direct contact with the market, looking for a label ensuring the sustainability of fuels purchased at the pump.

It is likely that, in absence of heavy public subsides, biofuels at the pump might bear increased costs for drivers. Current biofuelprocessing technologies are indeed scarcely efficient, and heavy $R \& D$ investments are under way to develop better means to extract and produce $2 \mathrm{G}$ biofuels. It can be speculated that the costs of research and future installation means will lead to (at least temporary) spikes in prices, and it is hence interesting to analyze if drivers are actually willing to pay an extra. Moreover, public policies to spur biofuels are changing rapidly, in the wake of increasing concerns of the effective benefits achieved as well as the costbenefit analyses carried out (Kutas et al., 2007). In the EU, most Member States including Germany (world leader in biodiesel production) experienced an (at least partial) substitution of fiscal incentives with "command and control" instruments such as obligations to blend (Ninni, 2010). Concerns that the former should be reduced but not eliminated as to mitigate negative effects on the price of biofuels have also been raised. Also in Brazil, where the ethanol industry is highly competitive, there is a debate on the need to decrease fiscal incentives to find a balance between the competitiveness of the sector and lost revenues for public bodies (Cavalcanti et al., 2012). The US are also including blending mandates for biofuels (as encompassed by the Renewable Fuel Standard) coupled with fiscal incentives (Grafton et al., 2014), and similar patterns feature energy policies in most emerging economies such as China and India, where fiscal incentives are coupled 
with blending mandates although at regional/state rather than national level (Hassan and Kalam, 2013).

As far as consumers' WTP for cleaner energy is concerned, most of the evidence in literature focuses on empirical investigations analyzing consumers' reaction to green pricing programs for electricity (Krishnamurthy and Kriström, 2014; Soon and Ahmad, 2015; Sundt and Rehdanz, 2014).

Few studies focus on the specific biofuel sector, since only in recent years ethanol (mainly produced in the US and Brazil) and biodiesel (mainly produced in the EU) reached relevant production figures (Anderson, 2012; Solomon and Johnson, 2009). Available evidence is not conclusive as different studies reach inconsistent results; however, it emerges a general pattern where drivers are willing to pay a little premium for ethanol, and WTP for E85 is higher than that for E10 given the broader environmental benefits associated with the former (Jensen et al., 2010; Petrolia et al., 2010 Susaeta et al., 2010). There is also evidence that some individuals would be accepting to run their vehicles on $2 \mathrm{G}$ ethanol only if available at a discounted price (Li and McCluskey, 2014), thus showing a negative WTP. Brazil has a long-established history of ethanol, since the PROALCOOL Programme of the 1970s (as today, there is a blending mandate of $25 \%$ ethanol at every gas station). Yet, empirical evidence on Brazilian consumers' WTP for ethanol is scant. Pouliot (2013) found that $20 \%$ of Brazilian drivers are willing to buy ethanol even if they have to pay a $10 \%$ premium over gasoline. Salvo and Huse (2013) found that a fifth of their sample is willing to buy ethanol even if the premium over gasoline reaches $20 \%$. However, both studies also found niches of consumers showing a negative WTP for ethanol, with a possible explanation being concerns about durability and performance.

Given the predominance of ethanol in the North American market, little attention has been devoted by US-based studies to biodiesel (Jeanty et al., 2007). As regards biodiesel in Europe, empirical evidence is scant and inconclusive. While for instance Giraldo et al. (2010) suggest that Spanish consumers have an average WTP for biodiesel of around 5 eurocents per liter $(0.054 €)$, Kallas and Gil (2014) found that drivers in Catalonia are not willing to pay any premium for biodiesel.

\section{Factors influencing pro-environmental behaviors}

Research on pro-environmental behavior and its predictors is vast (Bamberg and Möser, 2007; Hines et al., 1987; Lee et al., 2014 Steg et al., 2014). Many studies attempted at identifying the defining features of an ideal green consumer or the psychological processes explaining her behaviors (Blok et al., 2015; Maniatis, 2015). Early research consisted of correlational studies focusing on socio-demographic features in an attempt to segment the market as to profile green consumers, Socio-demographics are easy to apply to segmentation analyses; yet, they represent an oversimplification of a construct that is indeed complex and multifaceted, and this might be an explanation of inconsistent results reached in literature (Akehurst et al., 2012; Diamantopoulos et al., 2003). A preliminary hypothesis that we want to test is that indeed socio-demographics are not relevant predictors of a proenvironmental behavior such as the purchase of renewable fuels, expressed in terms of WTP:

H1. WTP for biofuels is not affected by specific socio-demographic characteristics of an individual

Psychographic characterization has also been proposed as a viable procedure to analyze green consumers (Bamberg and Möser, 2007; Hines et al., 1987), with psychological constructs such as altruism (Stern et al., 1993), environmental concern (Dunlap and
Jones, 2002) and values (Ramayah et al., 2010; Schwartz, 1992; Stern et al., 1995) singled out as predictors of pro-environmental intentions and, in turn, actual behaviors.

Mainstream literature however focuses on overarching theoretical frameworks analyzing the synergic effects of different and interrelated constructs, rather than on single variables. Various theories have been proposed to explain how we form our intention to adopt an environment-friendly behavior, the most influential being the Theory of Planned Behavior (TPB, Ajzen, 1985) and further extensions and integrations (Conner and Armitage, 1998).

The basic assumption is that behaviors are the outcome of a reasoned process affected by attitudes, norms and perceived behavior control. Attitudes represent the personal feeling of being more or less favorable towards performing an activity, subjective norms reflect social pressure as they define perceptions of how our referents would expect us to behave in given contexts, and perceived behavioral control represents the perception we have of how easy or difficult the uptake of a specific behavior is. The theory has been used in studies covering a wide range of behaviors and its predictive value proved to be good (Bamberg and Schmidt, 2003; Zhang et al., 2013).

Attitudes are hence a key predictor of pro-environmental behavior within the TPB framework, and it is speculated that environmental knowledge and awareness are in turn among the best predictors of green attitudes (Kollmuss and Agyeman, 2002). There is evidence that consumers highly knowledgeable about environmental issues positively affect the uptake of green behaviors (Laroche et al., 2001; Maniatis, 2015), and specifically the WTP for eco-friendly products (Amyx et al., 1994). The knowledge issue assumes particular relevance in the case of biofuels. Compared to other green purchasing behaviors (e.g. organic food), there is less awareness in the general public, and it is difficult to discern the environmental properties of a product that to most consumers appears undifferentiated. A second research hypothesis hence refers to the role played by awareness in spurring consumers' WTP for biofuels. We speculate that individuals with greater familiarity with the issue of biofuels should be willing to pay a higher premium price to run their vehicles on environment-friendly fuels, and we test this assumption by means of the following hypothesis:

H2). WTP for biofuels is higher in individuals declaring familiarity and knowledge of the topic

Green behaviors are interrelated with each other, exerting an interaction and a mutual influence. On the one hand, there are overarching subjective constructs (e.g. norms, values, awareness) affecting the uptake of a broad set of behaviors even in distant and not necessarily related domains. On the other hand, spillover theories such as Self Perception (Bem, 1972) or Cognitive Dissonance (Festinger, 1957) theories suggest that the uptake of a green behavior triggers psychological mechanisms so that it is more likely that also other green behaviors, even in distant domains, are carried out (Lanzini and Thøgersen, 2014; Thøgersen and Ölander, 2003). We want to shed light on the strength of such interaction, as we can speculate that individuals that are keen on purchasing green fuels (that is, individuals with higher WTP for biofuels) are also characterized by greener behavioral patterns as regards both green purchasing and curtailment behaviors. We want to investigate the relationship between WTP for biofuels and the aforementioned behavioral categories, and we do so by means of testing the following research hypotheses:

H3). WTP for biofuels is higher in individuals that usually purchase green products

H4). WTP for biofuels is higher in individuals with wellestablished green curtailment behaviors 


\section{The role of certification in the biofuel sector}

Certification is a form of communication along the supply chain allowing buyers and all interested parties to recognize whether a product complies with given criteria. Recent literature has proved that Ecolabels can be effectively used as communicational tools to drive consumers' behaviors towards greener products. For instance Testa et al. (2015) show how the use of the EU Ecolabel and the FSC certification are able to affect the choice to purchase green products in the tissue paper and detergent market segments. The same approach could work for biofuels, with certification being used to guide the choice of drivers "at the pump" by compensating information asymmetries and reducing uncertainty.

To date, there are different initiatives aimed at introducing sustainability criteria and certification schemes within the biofuel industry. As far as the European context is concerned, both the EU and single Member States are active in the field of bioenergy certification. EU set a binding target of $10 \%$ renewable fuels in the transport sector by 2020 for each Member State, as part of a broader energetic policy, the so-called 20-20-20 strategy, encompassing the simultaneous achievement by 2020 of $20 \%$ energy consumption from RES, 20\% reduction in GHG below 1990 levels and $20 \%$ increase in energy efficiency. The Renewable Energy Directive (RED, 2009/28/EC) asks for the setting up of a certification scheme for biofuels produced within the Union or imported from abroad: only those meeting specific criteria should be counted with reference to the achievement of national targets on the way of the 20-20-20 strategy, as well as for being eligible for financial support. The relevance of biofuel certification is mirrored by the growing academic production on the topic, with most articles focusing on issues ranging from the implications for international trade to the criteria to meet and the assessment methodologies (e.g. GHG emissions' reduction), or providing an overview of existing schemes and initiatives. There is indeed a plethora of studies providing a global overview on different certification schemes developed worldwide in the field of biofuels (Scarlat and Dallemand, 2011,Van Dam et al., 2010) and, notwithstanding different scopes of research and aims of analysis, there are some common trends that link most of the existing literature. For instance, the need for a process of homogenization and harmonization of existing schemes (Junginger et al., 2011; Scarlat and Dallemand, 2011; Van Dam et al., 2010) or the environmental dimensions taken into account by different schemes, and specifically the scarce attention that up to recent years have been devoted to a crucial aspect such as that of Indirect Land Use Changes (Scarlat and Dallemand, 2011; Van Dam et al., 2010).

Certification represents a possible answer to the need to ensure that biofuel production and commercialization are sustainable and satisfying specific environmental and social criteria. While most of existing initiatives focus on the aspects of international trade and the feedstock-producers/industrial processors relationship, the market of end-consumers has received so far no attention as to date there are no biofuel ecolabels used as communicational tools to drive consumers' behaviors at the pump. The present paper shifts the core of interest downstream, envisaging the possibility of selling biofuels with a label ensuring their sustainability and assessing WTP of drivers with regard to both generic biofuels and certified ones. The work thus represents an added value in literature as it focuses on an aspect that has been so far neglected: assessing the potential of a biofuel eco-label in increasing the perception of benefits among consumers, and their WTP. The results could be of interest both for policy makers and for industrial actors producing and selling biofuels; it could indeed provide an important informational background on the effectiveness of a relevant communicational tool to bridge the gap between consumers and the industry and to change perception and behaviors of the former.

Given the uncertainties around the effective environmental benefits of biofuels and the diffidence among consumers deriving from greenwashing phenomena on the one hand and recent debates on the effectiveness of biofuels on the other, it is reasonable to expect that green certification granted by independent bodies might play a role in shaping WTP patterns. Starting from these considerations, we formulate the following hypothesis:

H5). Green certification positively influences consumers' WTP for biofuels

\section{Methods: survey data and empirical model}

The study is based on a sample of $260^{1}$ participants (mean age 34.0, 57.8\% females) recruited between June and December 2013 in the provinces of Venice, Padua and Brescia in Northern Italy. The data have been collected by means of an online questionnaire uploaded on the software Qualtrics. Besides some introductory questions on the personal background of participants (descriptive statistics on the sample are presented in Table 1), the sections of the questionnaire are devoted to investigate behavioral patterns of individuals, environmental awareness and WTP for alternative fuels. Intention to act in a pro-environmental way is assessed with respect to a battery of nineteen environment friendly behaviors, using the format: How often do you think you will do " $X$ " over the next months? (where " $\mathrm{X}$ " stands for each behavior), rated on a 5point scale ranging from $1=$ never to $5=$ always plus and additional option don't know/does not apply. The behaviors cover the domains of transport mode, recycling, energy/water conservation and green purchasing, which are the main macro-categories in most research on pro-environmental behavior (Thøgersen and Ölander, 2003). As regards purchasing behaviors, respondents are asked how often they buy each of the following items: 1 ) organic fruit; 2) organic vegetables; 3 ) organic meat; 4) organic milk and 5) other dairy products; green labeled 6) soaps; 7) cleaning products; 8) toilet and 9) other tissue paper. A common factor analysis was applied to responses, and one factor emerged to account for green purchasing behavior (Cronbach alpha $=0.87$ ). As regards curtailment (that is, non-purchasing) behaviors, respondents are asked how often they carry out each of the following activities: 1) turning off the light upon leaving a room;2) turning off the water while brushing teeth;3) turning off the water while lathering the soap; 4) recycling paper; 5) recycling plastics; 6) recycling glass. An overall curtailment behavior score obtained from indexing the scores on each of the six items is used, accounting for both the frequency and amplitude of an individual's environmental behavior (Cronbach alpha $=0.74$ ).

The subsequent section focuses on biofuels, investigating awareness and knowledge of the topic among the sample, asking participants how would you define you knowledge of biofuels? on a 5point scale ranging from Very poor/Don't know what they are (1) to Very good (5).

Then, WTP for alternative fuels is assessed, and to this end the sample has been randomly split into two groups (labeled as the

\footnotetext{
${ }^{1}$ The sample size is consistent with most literature on the topic including studies mentioned in the article, or even larger (Giraldo et al., 2010; Li and McCluskey, 2014; Salvo and Huse, 2013), although there are also works based on larger samples exceeding one thousand respondents (Jensen et al., 2010; Solomon and Johnson, 2009).
} 
Table 1

Descriptive statistics.

\begin{tabular}{llccc}
\hline Variable & Observation & Mean & Standard deviation & Max \\
\hline WTP for biofuel & 243 & 1.530 & 0.963 & 0 \\
Awareness on Biofuel & 258 & 2.511 & 0.887 & 1 \\
Purchasing behavior & 249 & 0.001 & 0.969 & -2.872 \\
Curtailment behavior & 255 & 0.001 & 0.949 & -6.209 \\
Certification & 260 & 0.442 & 0.497 & 0 \\
Socio-demographics factors & & & & \\
Age & 247 & 33.975 & 12.725 & 19 \\
Gender $^{\text {a }}$ & 256 & 1.570 & 0.496 & 1 \\
Education $^{\text {b }}$ & 257 & 3.412 & 0.734 & 70 \\
\hline
\end{tabular}

a $1=$ male; 2 = female

b $1=$ elementary school; 2 = middle school; 3 = high school; $4=$ university degree; 5 = more than university degree.

certification vs no certification conditions), which had to complete two surveys that diverged with reference to the specific question on WTP, only. While for respondents in the no certification condition the question referred to a generic biofuel obtained from renewables, the question in the certification condition specifically referred to a biofuel obtained from renewables, which received a green label granted by an independent third-party organization, certifying that it complied with specific environmental criteria (e.g. avoidance of competition for land). To measure the role of biofuel certification we construct a binary variable assigning 1 to respondents in the "certification" group and 0 to respondents in the "no certification" group. We adopt a contingent valuation method (Venkatachalam, 2004) to elicit WTP of participants, asking them to state the maximum premium price they would accept to pay (per liter) in order to purchase biofuels derived from renewable sources instead of traditional, fossil-based fuels. Possible answers ranged from $0.00 €$ to $0.20 €$ (with 1 eurocent intervals), with additional options being Don't know/Don't drive and More than $0.20 € \epsilon^{2}$ We assign 0 to the categorical variable on WTP for respondents declaring to be unwilling to pay any premium price for biofuels; 1 for respondents willing to pay an extra $0.01 €-0.07 € ; 2$ for respondents willing to pay an extra $0.08 €-0.14 €$ and 3 for respondents willing to pay a premium larger than $0.14 €$.

To test our hypotheses we construct an equation where WTP for biofuels represents the dependent variable, whose categorical nature allows performing an ordinal logistic regression. We first run some preliminary tests required by the nature of the model, which assumes that the cumulative odds ratio for any two values of the covariates is constant across response categories (Peterson and Harrell, 1990). We positively test this assumption by applying a likelihood ratio test where the null hypothesis is that there is no difference in the coefficients among models. Moreover, we check the presence of collinearity by computing the tolerance and variance inflationary factor (VIF) for all variables. Low variance inflation factors $(<2.0)$ and low VIF $(<5)$ reveal that multicollinearity is not present in our empirical model (O'Brien, 2007). Since we circulated an online survey to collect data, we investigate the presence of common method variance by conducting a post-hoc statistical tests, the Harman's single-factor test: all the variables are included in an exploratory factor analysis and, if a single factor emerges as accounting for the majority of covariance among the variables, there is an indication that common method variance occurs. The test reveals the presence of four factors with eigenvalue greater than 1.0 accounting for $64 \%$ of the total variance, the greater of which accounting for $24 \%$.

\footnotetext{
2 The willingness to accept a premium price has been measured by our study in absolute values, therefore our results should be seen as related to the price of 1 lt of fuel at the pump in the period in which the survey has been carried out, which ranged from $1.5 € /$ liter to $1.6 € /$ liter.
}

\section{Results}

The dependent variable we have selected for our model is a proxy of the willingness to buy biofuel, since this product once commercialized on large scale might entail a premium price "at the pump" due to high R\&D costs. In light of this, measuring the WTP is the most effective way to check the real availability of potential consumers (drivers) to purchase the product. Almost one fifth of the respondents of our survey (17.7\%) declare their unwillingness to pay any premium price for biofuels. $29.2 \%$ are willing to pay a little premium of up to 7 eurocents, while $39.9 \%$ are willing to pay up to 14 eurocents. Only a small set of respondents (13.2\%) declares high WTP for biofuels, exceeding 14 eurocents per liter.

The results of our model provide new and valuable insights on which factors influence consumers' WTP for biofuels (Table 2 and Fig. 1).

We have firstly investigated the role played by specific sociodemographic factors. Consistently with recent literature on the topic (Akehurst et al., 2012; Zhao et al., 2014), our results suggest that the so-called "green consumer" cannot be easily classified in a well-defined sociological profile regarding her personal status and/ or demographical characteristics, as it was believed in early studies on consumer behavior. Indeed, all these variables are not significantly related to the WTP a premium price for biofuels: the only exception is represented by pensioners being less likely to pay more for biofuels if compared to students (the coefficient is negative and statistically significant at $90 \%$ ). This first outcome of the model confirms the inadequacy of many marketing approaches which are primarily focused on consumer profiling and on demand characterization. Such approaches are largely based on the common assumption that there are socio-demographical variables able to strongly affect consumer choices; our result rebuts this assumption for the biofuel market and positively tests Hypothesis 1.

Another significant outcome of our model is that the awareness on biofuels is highly significant in determining the unavailability to pay a premium price for biofuels (the coefficient of "Awareness on Biofuel" variable is negative and significant at 99\%). The more consumers are familiar with biofuels, the less they are willing to pay a premium price for such (supposedly) sustainable fuels: the probability of consumers not be willing to pay a premium for biofuels is 0.6 time higher for aware and well-informed individuals. Therefore, Hypothesis 2 is inversely supported. While most of the evidence on sustainable consumption suggests that well-informed consumers are more likely to purchase environment-friendly products, even when they are more expensive than "conventional" alternatives (Ha and Janda, 2012; Testa et al., 2015), biofuels represent an exception as our results confirm the fears that years of negative campaigning on the environmental impact of first generation biofuels still impact on consumers' views on the product. This is consistent with the study of Delshad and Raymond (2013), 
Table 2

Regression results.

\begin{tabular}{|c|c|c|c|}
\hline Dependent Variable: WTP for biofuel & Coefficient & Marginal effect & Standard error \\
\hline Awareness on Biofuel & $-0.509^{* * *}$ & 0.600 & 0.168 \\
\hline Purchasing behavior & $0.438^{* * *}$ & 1.549 & 0.157 \\
\hline Curtailment behavior & 0.104 & 1.110 & 0.514 \\
\hline Certification & -0.163 & 1.007 & 0.265 \\
\hline \multicolumn{4}{|l|}{ Socio-demographics factors } \\
\hline Age & 0.007 & 0.978 & 0.019 \\
\hline Gender & -0.021 & 1.051 & 0.301 \\
\hline Level of education & 0.050 & 0.064 & 0.203 \\
\hline Occupation held: pensioner (compared with student) & $-2.748^{*}$ & 0.064 & 1.461 \\
\hline Occupation held: unemployed (compared with student) & 0.498 & 1.647 & 0.910 \\
\hline Occupation held: salaried employee (compared with student) & 0.210 & 1.234 & 0.530 \\
\hline Occupation held: self-employee (compared with student) & -0.552 & 0.575 & 0.653 \\
\hline Occupation held: housewife (compared with student) & 0.367 & 1.444 & 0.940 \\
\hline Occupation held: worker (compared with student) & 14.783 & 0.263 & 812.004 \\
\hline Occupation held: business executive (compared with student) & -0.301 & 0.739 & 0.962 \\
\hline Occupation held: other (compared with student) & 0.810 & 2.249 & 0.880 \\
\hline \multicolumn{4}{|l|}{$\mathrm{Chi}^{2 * * *}$} \\
\hline \multicolumn{4}{|l|}{ Pseudo- $R^{2}: 0.0663$} \\
\hline $\mathrm{N}^{\circ}$ of observations: 215 & & & \\
\hline
\end{tabular}

${ }^{*},{ }^{* *}$, and ${ }^{* * *}$ indicate significance at $10 \%, 5 \%$, and $1 \%$, respectively.

analyzing the effects of negative biofuel campaigning (in terms of media framing) on consumers. The shift of media framing and the resulting increase in negative messages on biofuel drawbacks (e.g. food vs fuel controversy) had a negative effect on public attitudes towards biofuels, which can be regarded as a proxy of consumers' WTP. According to the study, not only the more people are attentive to news on biofuels, the less supportive of their diffusion they become. Moreover, individuals that are more concerned by sustainability issues are found not to discriminate between traditional and advanced biofuels. The effects of negative campaigning on the drawbacks of traditional biofuels still haunt $2 \mathrm{G}$ alternatives indeed, especially in environmentalists. Similarly, Dragojlovic and Einsiedel (2015) demonstrate such propagating effect in an experimental setting: when negative arguments are raised against a specific $2 \mathrm{G}$ biofuel (use of woody biomass leading to increased logging and deforestation), individuals experience a steady decrease in the support of advanced biofuels even from feedstock other than woody biomass (thus lacking this specific drawback). A negative relation between the level of "familiarity" with (and knowledge of) biofuel and the WTP can also be explained by a general tendency by "experts" to underestimate the additional costs linked to an innovative technology or technique. The premium price is normally justified by a higher cost of production and/or by the need to internalize negative externalities connected to a product. In the case of biofuels, a greater awareness and knowledge of the process might have induced in those familiar with this "innovation" a lower WTP because experts do not see higher costs in the generation phase and/or they think that conventional fuels should have a higher price due to the need of internalizing considerable externalities.

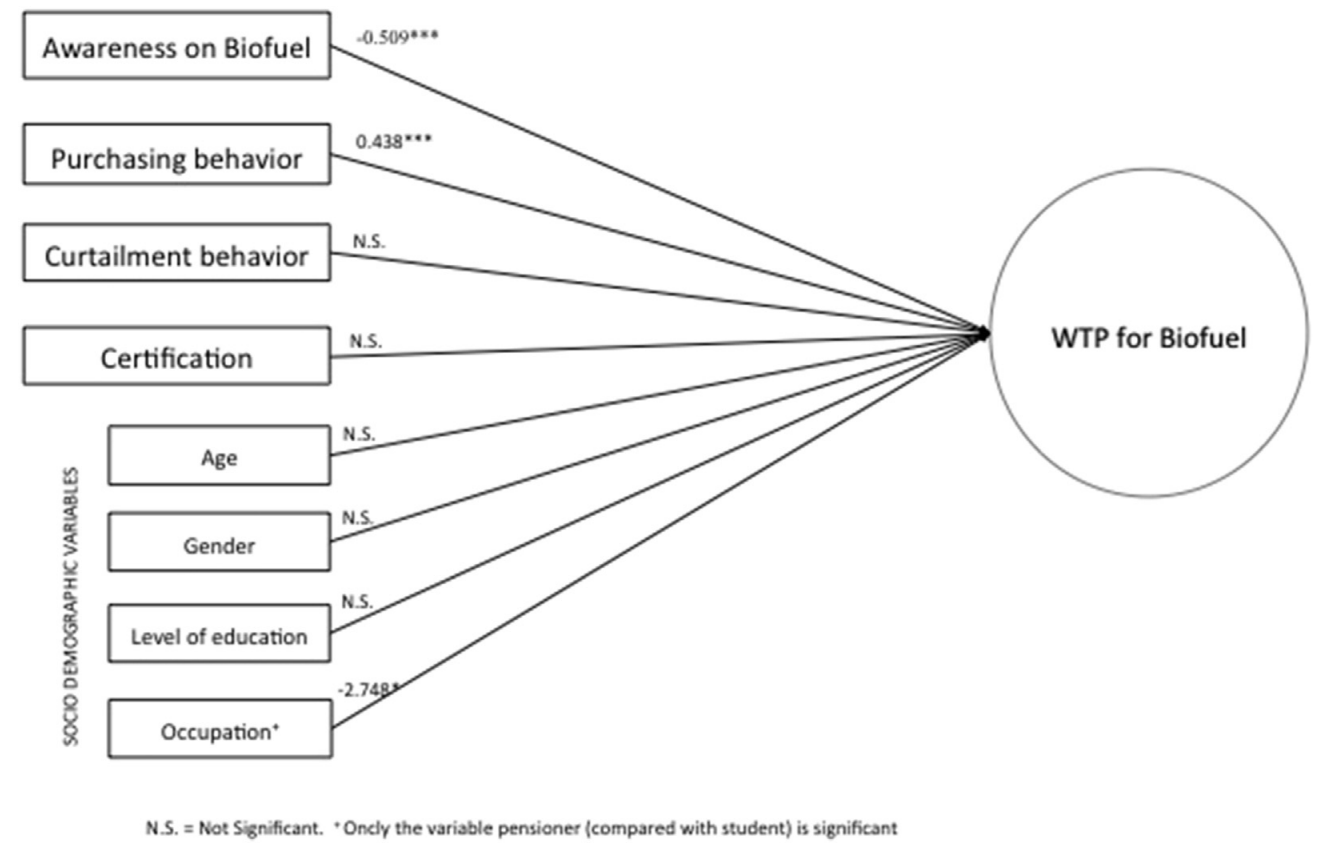

Fig. 1. Graphical representation of regression results. 
As regards the role played by broader behavioral patterns in affecting WTP for biofuels, we wanted to investigate if consumers that are used to adopt other green behaviors are keener on paying a premium to purchase biofuels. We need here to make a distinction between purchasing and non-purchasing behaviors. On the one hand, results show how the probability of a consumer that habitually purchases green products to be willing to pay more for biofuels is 1.5 times higher than a consumer who is less used to buy green products (the coefficient of "Purchasing behavior" variable is positive and significant at $99 \%$ ). On the other hand, no significant relation between curtailment behaviors and WTP for biofuels emerges (the coefficient of "Curtailment behavior" variable is not significant). Therefore, our results support Hypothesis 3 whereas they do not support Hypothesis 4.

Purchasing and curtailment behaviors are two different expressions of so-called private-sphere environmentalism (Stern and Gardner, 1981); as such, it is not surprising that their effects on the WTP for biofuels diverge. Drivers at the gas station are carrying out a purchasing rather than curtailment activity, so that the mental process followed in the development of behavioral intentions is linked to that of other products' purchases. This means that drivers that are used to buy green products in other market segments (especially on the final market) are also more acquainted to the need to pay a premium price for these kinds of products, as to obtain a better environmental performance, and they mirror this attitude in their responses to the questionnaire. Whereas respondents that are more familiar with curtailment behaviors are used to make choices and adopt lifestyles that normally imply an economic saving if compared to "conventional" behavior or purchase of products (i.e.: energy efficiency, water savings, waste recovery, use of public transportation, etc.). It is also worth mentioning how the results of the model highlight the role of habits and routine as drivers of green consumption. As stressed in the theoretical framework on behaviors designed by Stern (2000) and Ajzen and Fishbein (2010), the behavioral pattern can be a determining factor to predict a specific behavior. The significance of the variable "purchasing behavior" demonstrates that consumers used to buy green product are more likely to continue to buy a green version of a new product.

A key aspect of our study is represented by the role of certification in spurring WTP for biofuels. Consumers cannot verify directly the environmental quality of biofuels, so that it can be inferred that they might rely on third-party information capable of certifying that a specific fuel complies with given environmental criteria (King et al., 2012). In contrast with prior evidence (Xu et al., 2012), the results of our study surprisingly do not support Hypothesis 5 suggesting that certification is not an effective tool in influencing WTP for biofuels (the coefficient of "Certification" variable is not significant). The possible explanation can be found in the aforementioned "experts' bias" (they are keener to take certification and labels into account when buying a product) and in the effects of information about some side-effects of first-generation biofuels, which are difficult to overcome. Indeed, even if a certification mechanism may provide a guarantee for $2 \mathrm{G}$ biofuels assuring consumers on the reduced environmental impact of their life cycle, the negative effects of previous information campaigns seem to be still alive in their memory.

\section{Discussion and conclusions}

The results of our model have implications both for policies and for managerial strategies. The first and most relevant implication for policies concerns the lower WTP shown by those consumers who are more aware and well informed on biofuels. Public policies aiming to support a demand-pull diffusion of biofuels on the market should hence cope with this problem: there is a clear tendency by the "upper" share of the market to refuse to pay a premium price for biofuels.

Negative campaigning and heterogeneous findings regarding the sustainability of biofuels, coupled with the uncertainties that still linger on $2 \mathrm{G}$ ones, dazed consumers; especially, those with higher awareness and interest in the topic. To spur public acceptability, a stepwise approach seems necessary. First, there is the need to shed more light on the effective advantages of advanced biofuels, addressing the aforementioned grey areas. Then, once scientific consensus over the most effective pathway to produce biofuels is reached, adequate and consistent information should be provided to consumers. For instance, the pricing of biofuels should be better motivated by clarifying what are the environmental advantages and the higher production costs that justify the premium price. This has obviously to be referred to $2 \mathrm{G}$ biofuels, and specifically to those proving to be more sustainable. Strong efforts by public institutions in promoting their use by consumers and spreading on the market represent a prerequisite for the success of a biofuel market.

In other words, consumers need to receive consistent and adequate information on the environmental and social impacts of biofuels, and on the reasons why "some" $2 \mathrm{G}$ biofuels are more sustainable than traditional ones. Else, providing confused and incoherent messages would have biofuels suffer from a negative bias in the purchasers' perception, probably built on negative campaigns that have been carried out so far on traditional biofuels.

Third-party certification does not emerge as a viable solution from our study (Hypothesis 5 is not supported). Again, aware and better informed consumers would be negatively influenced by the presence of an ad-hoc certification on biofuels when they purchase "at the pump". This result could be affected by the fact that there is no certification scheme available and used by producers in their retailing channels yet. But the upper share of the market seems to be hypothetically less prone to pay a premium price for a biofuel that has been independently certified to be compliant with keycriteria of environmental protection. The most significant policy implication relates once again to the need of clearly explaining the meaning of the certification and the environmental advantages it guarantees, otherwise this will not be accepted by "evolved" consumers.

A possible way to overcome this drawback is suggested by another evidence emerging from our study. Those consumers that are more frequently adopting "green" purchasing behaviors are keener to buy biofuels. Since previous studies demonstrated the positive role of certification in supporting green consumption (Testa et al., 2015), future research may investigate the relationship between WTP for biofuels and familiarity with other (non sectorspecific) forms of certification in other markets (such as: household products, office equipment, fashion products, etc.). Such analysis might investigate which characteristics a certification scheme should have in order to reassure consumers on the environmental benefits of biofuels.

This could imply a further suggestion for policy makers concerning the use for biofuels of ISO type I or type III environmental labeling schemes that are already widespread and accepted on other market segments, such as the EU Ecolabel (type I) or existing EPD schemes (type III) in the EU market. In particular, an additional advantage of using third-party ISO type I eco-labeling schemes, especially when the program operator is a public body such as in the case of the EU Ecolabel, is related to the higher effectiveness in providing guarantees under the ethical point of view. What happened in the case of animal testing is quite significant in this respect. For some product categories (e.g.: cosmetic products) the European Commission has been forced by stakeholder pressures to 
introduce criteria against animal testing. This has strongly enhanced the reputation and reassured the stakeholders (and consumers in particular) on the ethical reliability of this ecolabeling scheme. The same process could be applied for the "land use" related issues when including biofuels in a new EU Ecolabel product group.

Some implications of our work can be identified also for managerial strategies. First of all, pricing should take into account the factors that influence the WTP shown by consumers. There is a clear signal for producers concerning the actual and potential drawbacks and difficulties that biofuels have to face to make consumers accept a premium price: the negative perceptions on biofuels not "deserving" this premium price, especially in the upper share of the market, can create a strong barrier. And even when a new ad-hoc third-party certification is adopted to emphasize the credibility and the reliability of the biofuel, this would be negatively associated with the WTP. The most effective and reasonable approach to pricing, in this case, is to keep the mark-up at low levels accepting a longer payback period for the innovative product. In the meanwhile, as for policies, communication strategies to consumers should insist on the real environmental advantages and benefits of biofuels, in order to overcome the negative bias by the "experts", providing reliable data and quantitative information on environmental impacts.

Second, if we couple this last indication with the positive correlation of the WTP with green purchasing behaviors, we can derive another key-implication for marketing: communication strategies towards the final consumer (driver) on biofuels should mainly rely on tools and channels that are already used in other markets to promote "green products". As it emerges from our study, consumers that are already familiar with these tools and channels would probably be the best target for biofuels as their WTP is definitely higher.

A last important finding of our study also pertains to marketing strategies. The outcome of the model supports the idea that a univocal definition of the "green consumer" on the basis of social and cultural attributes is totally ineffective. As anticipated, this confirms the findings of recent marketing studies on consumers, holding that socio-demographics are not relevant predictors of a pro-environmental behavior. Specific marketing implications in the biofuel sector pertain to market intelligence: consumer profiling and targeting should definitely rely on interpretative models based on multiple variables, that are able to explain "green purchasing" decisions as a multi-faceted process. Within this process, both demand-related (e.g.: norms, values, beliefs, etc.) and supplyrelated (price, performance, product certification, etc.) variables do interact influencing the final decision of consumers (Iraldo and Melis, 2011).

A limitation of the study is represented by the fact that proenvironmental behaviors (including a proxy of biofuel purchase such as consumers' WTP) are self-reported (Kormos and Gifford, 2014). As a consequence, results might overestimate for instance the share of the market (over $80 \%$ of our sample) that is actually willing to pay a premium for biofuels, due to pro-social biases in responses. More research based on observed rather than selfreported behaviors is needed to integrate the evidence emerging from the present work.

Another useful integration that we leave to future research is represented by an assessment of respondents' effective knowledge of biofuels by means of specific questions investigating their familiarity with the topic, rather than a self-assessment of the latter. A third possible integration is represented by the replication of the study in different national contexts, or even in areas with different socio-economic features within the same Country (i.e. northern vs southern Italy). This would allow to gain insights on both common trends and features that are area-specific, with beneficial effects on the capability of public bodies to set up and implement effective policies fitting with any given context.

\section{References}

Ajzen, I., 1985. From Intentions to Actions: a Theory of Planned Behavior. In: Kuhl, J., Beckham, J. (Eds.), Action Control: from Cognition to Behavior. Springer, Heidelberg.

Ajzen, I., Fishbein, M., 2010. Predicting and Changing Behaviour. The Reasoned Action Approach. Psychology Press (Taylor \& Francis), New York.

Akehurst, G., Afonso, C., Martins Gonçalves, H., 2012. Re-examining green purchase behaviour and the green consumer profile: new evidences. Manag. Decis. 50 (5), 972-988.

Amyx, D.A., DeJong, P.F., Lin, X., Chakraborty, G., Wiener, J.L., 1994. Influencers of purchase intentions for ecologically safe products: an exploratory study. In Park, C.W., et al. (Eds.), AMA Winter Educators' Conference Proceedings, Vol. 5. American Marketing Association, Chicago, IL, pp. 341-347.

Anderson, S.T., 2012. The demand for ethanol as a gasoline substitute. J. Environ. Econ. Manag. 63 (2), 151-168.

Bamberg, S., Möser, G., 2007. Twenty years after Hines, Hungerford, and Tomera: a new meta-analysis of psycho-social determinants of pro-environmenta behaviour. J. Environ. Psychol. 27 (1), 14-25.

Bamberg, S., Schmidt, P., 2003. Incentives, morality, or habit? Predicting students car use for university routes with the models of Ajzen, Schwartz, and Triandis. Environ. Behav. 35 (2), 264-285.

Bem, D.J., 1972. Self-perception theory. In: Berkowitz, L. (Ed.), Advances in Experimental Social Psychology, Vol. 6. Academic Press, New York, pp. 1-62.

Blok, V., Wesselink, R., Studynka, O., Kemp, R., 2015. Encouraging sustainability in the workplace: a survey on the pro-environmental behaviour of university employees. J. Clean. Prod. 106, 55-67.

Borrion, A.L., McManus, M.C., Hammond, G.P., 2012. Environmental life cycle assessment of lignocellulosic conversion to ethanol: a review. Renew. Sustain. Energy Rev. 16 (7), 4638-4650.

Browne, D., O'Mahony, M., Caulfield, B., 2012. How should barriers to alternative fuels and vehicles be classified and potential policies to promote innovative technologies be evaluated? J. Clean. Prod. 35, 140-151.

Börjesson, P., Tufvesson, L.M., 2011. Agricultural crop-based biofuels-resource efficiency and environmental performance including direct land use changes. J. Clean. Prod. 19 (2), 108-120.

Cavalcanti, M., Szklo, A., Machado, G., Arouca, M., 2012. Taxation of automobile fuels in Brazil: does ethanol need tax incentives to be competitive and if so, to what extent can they be justified by the balance of GHG emissions? Renew. Energy 37 (1), 9-18.

Cherubini, F., Bird, N.D., Cowie, A., Jungmeier, G., Schlamadinger, B., WoessGallasch, S., 2009. Energy-and greenhouse gas-based LCA of biofuel and bioenergy systems: key issues, ranges and recommendations. Resour. Conservation Recycl. 53 (8), 434-447.

Chin, H.C., Choong, W.W., Alwi, S.R., Mohammed, A.H., 2014. Issues of social acceptance on biofuel development. J. Clean. Prod. 71, 30-39.

Chum, H.L., Zhang, Y., Hill, J., Tiffany, D.G., Morey, R.V., Goss Eng, A., Haq, Z., 2014 Understanding the evolution of environmental and energy performance of the US corn ethanol industry: evaluation of selected metrics. Biofuels, Bioprod. Biorefining 8 (2), 224-240.

Conner, M., Armitage, C.J., 1998. Extending the theory of planned behavior: a review and avenues for further research. J. Appl. Soc. Psychol. 28 (15), 1429-1464.

Delshad, A., Raymond, L., 2013. Media framing and public attitudes toward biofuels. Rev. Policy Res. 30 (2), 190-210.

Diamantopoulos, A., Schlegelmilch, B.B., Sinkovics, R.R., Bohlen, G.M., 2003. Can socio-demographics still play a role in profiling green consumers? A review of the evidence and an empirical investigation. J. Bus. Res. 56 (6), 465-480.

Doornbosch, R., Steenblik, R., 2007. Biofuels - Is the Cure Worse than the Disease? Official Report by the Organisation for Economic Co-operation and Development (OECD) Presented at the Round Table on Sustainable Development. Paris, 11-12 September 2007.

Dragojlovic, N., Einsiedel, E., 2015. What drives public acceptance of secondgeneration biofuels? Evidence from Canada. Biomass Bioenergy 75, 201-212.

Dunlap, R.E. Jones, R.E, 2002. Environmental concern: conceptual and measurement issues. In: Dunlap, R.E., Michelson, W. (Eds.), Handbook of Environmental Sociology. Greenwood Press, Westport, CT., pp. 482-524

Fargione, J., Hill, J., Tilman, D., Polasky, S., Hawthorne, P., 2008. Land clearing and the biofuel carbon debt. Science 319 (5867), 1235-1238.

Festinger, L., 1957. A Theory of Cognitive Dissonance. Row and Peterson, Evanston, IL.

Fleming, J.S., Habibi, S., MacLean, H.L., 2006. Investigating the sustainability of lignocellulose-derived fuels for light-duty vehicles. Transp. Res. Part D Transp. Environ. 11 (2), 146-159.

Frank, S., Böttcher, H., Havlík, P., Valin, H., Mosnier, A., Obersteiner, M., Schmid, E., Elbersen, B., 2013. How effective are the sustainability criteria accompanying the European Union 2020 biofuel targets? GCB Bioenergy 5, 306-314.

Giraldo, L., Gracia, A., Do Amaral, E., 2010. Willingness to pay for biodiesel in Spain: a pilot study for diesel consumers. Span. J. Agric. Res. 8 (4), 887-894. 
Grafton, R.Q., Kompas, T., Van Long, N., To, H., 2014. US biofuels subsidies and $\mathrm{CO}_{2}$ emissions: an empirical test for a weak and a strong green paradox. Energy Policy 68, 550-555.

Graham-Rowe, D., 2011. Agriculture: beyond food versus fuel. Nature 474 (7352) S6-S8.

Ha, H., Janda, S., 2012. Predicting consumer intentions to purchase energy-efficient products. J. Consumer Mark. 29, 461-469.

Hassan, M.H., Kalam, M.A., 2013. An overview of biofuel as a renewable energy source: development and challenges. Procedia Eng. 56, 39-53.

Hoefnagels, R., Smeets, E., Faaij, A., 2010. Greenhouse gas footprints of different biofuel production systems. Renew. Sustain. Energy Rev. 14 (7), 1661-1694.

Hines, J.M., Hungerford, H.R., Tomera, A.N., 1987. Analysis and synthesis of research on responsible environmental behaviour: a meta- analysis. J. Environ. Educ. 18, 1-8. Iraldo, F., Melis, M., 2011. Green Marketing. Sole24ore, Milano.

Jeanty, P.W., Haab, T., Hitzhusen, F., 2007. Willingness to pay for biodiesel in diesel engines: a stochastic double bounded contingent valuation survey. In: American Agricultural Economics Association Annual Meeting (Portland, Oregon, USA).

Jensen, K.L., Clark, C.D., English, B.C., Menard, R.J., Skahan, D.K., Marra, A.C., 2010 Willingness to pay for E85 from corn, switchgrass, and wood residues. Energy Econ. 32 (6), 1253-1262.

Junginger, M., Van Dam, J., Zarrilli, S., Ali Mohamed, F., Marchal, D., Faaij, A., 2011 Opportunities and barriers for international bioenergy trade. Energy Policy 39 (4), 2028-2042.

Kallas, Z., Gil, J.M., 2014. Consumers' preferences towards biodiesel in the Spanish transport sector: a case study in Catalonia. August 26-29, 2014, Ljubljana, Slovenia (No. 182801). In: 2014 International Congress. European Association of Agricultural Economists.

King, A., Prado, A.M., Rivera, J., 2012. Industry self regulation and environmental protection. In: Bansal, P., Hoffman, A.J. (Eds.), The Oxford Handbook of Business and the Natural Environment. Oxford University Press.

Kollmuss, A., Agyeman, J., 2002. Mind the Gap: why do people act environmentally and what are the barriers to pro-environmental behavior? Environ. Educ. Res. 8 (3), 239-260.

Krishnamurthy, C.K., Kriström, B., 2014. Determinants of the price-premium for Green Energy: evidence from an OECD cross-section. Environ. Resour. Econ. 1-32.

Kormos, C., Gifford, R., 2014. The validity of self-report measures of proenvironmental behavior: a meta-analytic review. J. Environ. Psychol. 40 359-371.

Kutas, G., Lindberg, C., Steenblik, R., 2007. Biofuels-at what Cost?: Government Support for Ethanol and Biodiesel in the European Union. International Institute for Sustainable Development, Geneva, Switzerland.

Lanzini, P., Thøgersen, J., 2014. Behavioural spillover in the environmental domain: an intervention study. J. Environ. Psychol. 40, 381-390.

Laroche, M., Bergeron, J., Barbaro-Forleo, G., 2001. Targeting consumers who are willing to pay more for environmentally friendly products. J. Consumer Mark. 18 (6), 503-520.

Lee, Y.K., Kim, S., Kim, M.S., Choi, J.G., 2014. Antecedents and interrelationships of three types of pro-environmental behavior. J. Bus. Res. 67 (10), 2097-2105.

Li, T., McCluskey, J.J., 2014. Consumer preferences for second-generation bioethano July 27-29, 2014, Minneapolis, Minnesota (No. 170203). In: 2014 Annual Meeting. Agricultural and Applied Economics Association.

Liska, A.J., Yang, H., Milner, M., Goddard, S., Blanco-Canqui, H., Pelton, M.P., Fang, X. Zhu, H., Suyker, A.E., 2014. Biofuels from crop residue can reduce soil carbon and increase $\mathrm{CO}_{2}$ emissions. Nat. Clim. Change 4 (5), 398-401.

Maniatis, P., 2015. Investigating factors influencing consumer decision-making while choosing green products. J. Clean. Prod. 1-14.

Ninni, A., 2010. Policies to support biofuels in Europe: the changing landscape of instruments. AgBioForum 13 (2), 131-141.

O'Brien, R., 2007. A caution regarding rules of thumb for variance inflation factors. Qual. Quantity 41, 673-690.

Peterson, B., Harrell, F.E., 1990. Partial proportional odds models for ordinal response variables. Appl. Stat. 39, 205-217.

Petrolia, D.R., Bhattacharjee, S., Hudson, D., Herndon, C.W., 2010. Do Americans want ethanol? A comparative contingent-valuation study of willingness to pay for E-10 and E-85. Energy Econ. 32 (1), 121-128.

Pouliot, S., 2013. Arbitrage between ethanol and gasoline: evidence from motor fue consumption in Brazil. In: Selected Paper Prepared for Presentation at the Agricultural \& Applied Economics Association's 2013 AAEA \& CAES Annua Meeting (Washington DC).

Ramayah, T., Lee, J.W., Mohamad, O., 2010. Green product purchase intention: some insights from a developing country. Resources, Conservation Recycl. 54 (12) 1419-1427.
Rathmann, R., Szklo, A., Schaeffer, R., 2010. Land use competition for production of food and liquid biofuels: an analysis of the arguments in the current debate. Renew. Energy 35 (1), 14-22.

Salvo, A., Huse, C., 2013. Build it, but will they come? Evidence from consumer choice between gasoline and sugarcane ethanol. J. Environ. Econ. Manag. 66 (2), 251-279.

Scarlat, N., Dallemand, J.F., 2011. Recent developments of biofuels/bioenergy sustainability certification: a global overview. Energy Policy 39, 1630-1646.

Schwartz, S.H., 1992. Universals in the content and structure of values: theoretical advances and empirical tests in 20 countries. Adv. Exp. Soc. Psychol. 25, 1-65.

Searchinger, T., Heimlich, R., Houghton, R.A., Dong, F., Elobeid, A., Fabiosa, J., Tokgoz, S., Hayes, D., Yu, T.H., 2008. Use of US croplands for biofuels increases greenhouse gases through emissions from land-use change. Science 319 (5867), 1238-1240.

Singh, A., Pant, D., Korres, N.E., Nizami, A.S., Prasad, S., Murphy, J.D., 2010. Key issues in life cycle assessment of ethanol production from lignocellulosic biomass: challenges and perspectives. Bioresour. Technol. 101 (13), 5003-5012.

Solomon, B.D., Johnson, N.H., 2009. Valuing climate protection through willingness to pay for biomass ethanol. Ecol. Econ. 68 (7), 2137-2144.

Soon, J.J., Ahmad, S.A., 2015. Willingly or grudgingly? A meta-analysis on the willingness-to-pay for renewable energy use. Renew. Sustain. Energy Rev. 44, 877-887.

Spatari, S., Bagley, D.M., MacLean, H.L., 2010. Life cycle evaluation of emerging lignocellulosic ethanol conversion technologies. Bioresour. Technol. 101 (2), 654-667.

Steg, L., Bolderdijk, J.W., Keizer, K., Perlaviciute, G., 2014. An integrated framework for encouraging pro-environmental behaviour: the role of values, situational factors and goals. J. Environ. Psychol. 38, 104-115.

Stern, P., 2000. Toward a coherent theory of environmentally significant behavior. J. Soc. Issues 56 (3), 407-424.

Stern, P., Dietz, T., Guagnano, G.A., 1993. Value orientations, gender and environmental concern. J. Soc. Issues 50 (3), 65-67.

Stern, P., Dietz, T., Kalof, L., Guagnano, G.A., 1995. Values, beliefs, and proenvironmental action: attitude formation toward emergent attitude objects. J. Appl. Soc. Psychol. 25, 1611-1636.

Stern, P.C., Gardner, G.T., 1981. Psychological research and energy policy. Am. Psychol. 36, 329-342.

Sundt, S., Rehdanz, K., 2014. Consumer's Willingness to Pay for Green Electricity: a Meta-analysis of the Literature (No. 1931). Kiel Working Paper.

Susaeta, A., Alavalapati, J., Lal, P., Matta, J.R., Mercer, E., 2010. Assessing public preferences for forest biomass based energy in the southern United States. Environ. Manag. 45 (4), 697-710.

Testa, F., Iraldo, F., Vaccari, A., Ferrari, E., 2015. Why Eco-labels can be effective marketing tools: evidence from a study on Italian consumers. Bus. Strategy Environ. 24, 252-265.

Thøgersen, J., Olander, F., 2003. Spillover of environment-friendly consumer behaviour. J. Environ. Psychol. 23 (3), 225-236.

Tilman, D., Socolow, R., Foley, J.A., Hill, J., Larson, E., Lynd, L., Pacala, S., Reilly, J., Searchinger, T., Somerville, C., Williams, R., 2009. Beneficial biofuels-the food, energy, and environment trilemma. Science 325 (5938), 270.

Van Dam, J., Junginger, M., Faaij, A.P., 2010. From the global efforts on certification of bioenergy towards an integrated approach based on sustainable land use planning. Renew. Sustain. Energy Rev. 14 (9), 2445-2472.

Venkatachalam, L., 2004. The contingent valuation method: a review. Environ. Impact Assess. Rev. 24 (1), 89-124.

Williams, P.R., Inman, D., Aden, A., Heath, G.A., 2009. Environmental and sustainability factors associated with next-generation biofuels in the US: what do we really know? Environ. Sci. Technol. 43 (13), 4763-4775.

Wiloso, E.J., Heijungs, R., de Snoo, G.R., 2012. LCA of second generation bioethanol: a review and some issues to be resolved for good LCA practice. Renew. Sustain. Energy Rev. 16 (7), 5295-5308.

Xu, P., Zeng, Y., Fong, Q., Lone, T., Liu, Y., 2012. Chinese consumers' willingness to pay for green-and eco-labeled seafood. Food Control 28 (1), 74-82.

Zhang, B., Yang, S., Bi, J., 2013. Enterprises' willingness to adopt/develop cleaner production technologies: an empirical study in Changshu, China. J. Clean. Prod. 40, 62-70.

Zhao, H.H., Gao, Q., Wu, Y.P., Wang, Y., Zhu, X.D., 2014. What affects green consumer behavior in China? A case study from Qingdao. J. Clean. Prod. 63, 143-151.

Zilberman, D., Hochman, G., Rajagopal, D., Sexton, S., Timilsina, G., 2013. The impact of biofuels on commodity food prices: assessment of findings. Am. J. Agric. Econ. 95 (2), 275-281. 